Research article

\title{
Comparative epidermal anatomical studies in six taxa of genus Nephrolepis Swart in Nigeria
}

\author{
A. A. Fajuke, A. M. Makinde, F. A. Oloyede and J. A. Akinloye* \\ Botany Department, Obafemi Awolowo University, Ile-Ife, Osun State, Nigeria \\ *Corresponding Author: ajakinloye@ gmail.com \\ [Accepted: 28 January 2018]
}

\begin{abstract}
Anatomical studies in six taxa of genus Nephrolepis; N. biserrata, N. cordifolia, N. exaltata (i) \& (ii), N. biserrata var. furcans and $N$. undulata were carried out with a view to identify anatomic characters of taxonomic values. Both qualitative and quantitative anatomical studies were carried out. Quantitative data were subjected to descriptive statistical analysis. Anatomical characters studied include venation patterns, trichome types, presence and absence of stomata and values of the stomatal index which are valuable in delimiting the species. The overall results showed overlaps in the quantitative anatomical attributes of the Nephrolepis taxa studied suggesting that they belong to the same genus. Qualitative anatomical attributes that separated the genus into distinct taxa are the presence of simple multicellular glandular trichomes in $N$. biserrata and simple multicellular non-glandular trichomes in $N$. exaltata (i) and $N$. exalta (ii) while $N$. biserrata var. furcans and $N$. undulata have simple unicellular non-glandular trichomes and absence of trichome in N. cordifolia. Presence of anisocytic, diacytic or anomocytic stomata were of diagnostic important in the six taxa.
\end{abstract}

Keywords: Anatomy - Stomata - Trichomes - Nephrolepis - Taxonomy.

[Cite as: Fajuke AA, Makinde AM, Oloyede FA \& Akinloye JA (2018) Comparative epidermal anatomical studies in six taxa of genus Nephrolepis Swart in Nigeria. Tropical Plant Research 5(1): 19-26]

\section{INTRODUCTION}

Nephrolepis Schott is a small genus of ferns that form groups of about 12,000 species in the world, with many found in the tropics (Carrington 2003). Alston (1959) reported five species of Nephrolepis in both Northern and Southwestern Nigeria, while Oloyede \& Odu (2011) reported six taxa of Nephrolepis in Southwestern Nigeria. The genus is made up of terrestrial, epiphytic, perennials and sometimes aquatic (growing in the marshy land). They are flowerless, seedless plants that require water at least during sexual reproduction (Sporne 1975, Oloyede \& Odu 2011). The leaflets are simple, sessile, small in size and possess a single median vein that fails to reach the apex. These leaves are hairy with serrated margins. The leaves of ferns are called fronds and consist of two main parts: the stipe which is the stalk that connects the leaf blade to the rhizome and the leaf blade or lamina that forms the leaf portion which expands outward from the rachis of the frond.

In ferns, the base of the frond grows faster than the tip which gives the frond a fiddle-head shape (Kenrick \& Crane 1997), this is called acropetal maturation. Leaf base in Nephrolepis could be cordate in N. furcans or truncate in N. exaltata (i) and (ii). The leaves are spirally arranged and densely cover the branches as a whorled in Lycopodium species (Bhambie 1965). They differ from the primitive thallophytes by having true leaves called megaphylls while they also differ from bryophytes by possessing vascular tissues (Carrington 2003).

The taxonomic values of anatomical features have been stressed by several workers including (Metcalfe \& Chalk 1950, 1979, Naik \& Nirgude 1981, Palmer \& Tucker 1981, Oloyede et al. 2011). Anatomical features sometimes prove useful in individual identification especially for materials that are not accompanied by flora parts or fruits and can be used to establish the botanical identity of commercial samples of medicinal plants (Metcalfe \& Chalk 1979). It has a lot of values in forensic Botany. Naik \& Nigurde (1981) stressed the value of anatomical characters and reported that anatomical characters provide additional features which along with other characters are of great taxonomic values in the classification and identification of plants. Essiet (2004) reported 
that anatomical features are widely used in systematic for identification, and placing anomalous groups in satisfactory position in classification and for indicating patterns of relationship that may have been observed by superficial convergence in morphological features.

Leaf epidermal features have been employed in taxonomy to separate plant genera and species (Scatena et al. 2005). The epidermis possesses a number of important diagnostic characters that offer valuable clues for identification like size, shape and orientation of stomata, guard cells and subsidiary cells, structural peculiarities of epidermal cells and stomata frequency (Munir et al. 2011). Saheed \& Illoh (2010) reported that guard cell area, stomatal index and frequency, presence or absence of trichomes as well as their length on epidermal surfaces and wall types are useful in separating the genera Senna and Chamaecrista from their initial genus Cassia. Oloyede et al. (2011) reported that the abaxial surface of $N$. biserrata and $N$. undulata showed that their epidermal cells were irregular in shape, while the stomata were diacytic, anomocytic and elliptic in shape. Crystal sand seen was numerous while non-glandular uniserrate multicellular trichome was seen in N. biserrata but absent in $N$. undulata. Watson \& Dallwitz (1992) described the important anatomical features of the family Cleomaceae with anomocytic, anisocytic, paracytic, actinocytic or cylocytic stomata found on the both the abaxial and adaxial surfaces. The presence and types of trichome have long been of considerable importance in comparative systematic investigations of angiosperm Metclfe \& Chalk (1979) and ferns (Oloyede et al. 2011). Crystals are diagnostic tools in plants for distribution, identification and taxonomy (Illoh \& Inyang 1995). In Nephrolepis biserrata and N. undulata, the common characters like epidermal cell structure, types of stomata, trichomes, crystals, venation patterns and morphological structures can be used to delimit the two species of the genus (Oloyede et al. 2011).

From literature, information on anatomical features of Nephrolepis genus in Nigeria is scanty. In this study, detail anatomical characters of the six taxa of Nephrolepis investigated were examined using Ligth Microscope with a view to (a) elucidate the similarities and differences that exits among the species and (b) fill the knowledge gap observed in the taxonomy of the group in Nigeria.

\section{MATERIALS AND METHODS}

\section{Collections of Accessions}

Accessions of the six samples of Nephrolepis studied were collected from various locations in Ile-Ife and planted at the biological garden of Obafemi Awolowo University, Ile-Ife, Osun State, Nigeria from where macro morphological data were collected. The collections were identified and authenticated at the IFE Herbarium. $N$. exaltata is only species that has two forms of leaf type; unipinnate at young stage [N. exaltata (i)] and bipinnate at maturity $[N$. exaltata (ii)] and treated here separately.

\section{Leaf clearing}

A sizeable portion of fresh mature leaflets of each taxa was taken from the standard median levels (that is midway between the apex and the base), washed and decolorized by boiling in 100\% ethanol for ten minutes to remove chlorophyll. The partially decolorized leaflets were washed carefully with 3-5 changes of water to remove all the traces of alcohol. The leaflets were boiled in sodium hydroxide solution for five minutes. Then soaked in 5\% domestic bleach (JIK) in Petri dish until they become completely decolorized. The leaflets were washed in five changes of water and then stored in 50\% ethanol. The leaflets were stained with Safranin O for 5 minutes and then mounted on a clean slide in $25 \%$ glycerol and the edges of the cover slip were sealed with nail hardener to prevent drying out. Both abaxial and adaxial surfaces of the leaflets were used to study venation patterns.

\section{Epidermal peel}

The cleared leaves were used because the stomata and epidermal anatomy were clearly visible under the microscope without peeling. Each taxa, 25 stomata were randomly selected in 20 fields from four prepared slides of the abaxial surface of each taxa. Stomata frequency was determined. The stomata index was estimated for the leaf surfaces using Cutter (1978) formula i.e. by expressing the number of stomata per unit area as a percentage of the total number of epidermal cells.

$$
\text { Stomata index }(I)=\frac{S}{E+S} X 100
$$

Where, $\mathrm{I}=$ Stomata index

$\mathrm{S}=$ number of stomata per unit area

www.tropicalplantresearch.com 
$\mathrm{E}=$ number of epidermal cells per unit area.

The guard cell area was calculated by multiplying the length and width of guard cell on the abaxial surface by Franco (1939) constant.

Where, Franco's constant $(\mathrm{k})=0.78524$

$$
\text { Guard cell area }=(\text { length } \times \text { width } \times \mathrm{k}) \mu \mathrm{m}^{2}
$$

\section{Sectioning}

Transverse sections (TS) of the leaf of the six taxa were made at $10 \mu \mathrm{m}$ thickness using the sledge microtome (Reichert, Austria). The sections were preserved in 50\% ethanol in vials prior to staining.

The sections were stained with Safranin O for five minutes, rinsed in water thrice and counter stained with Alcian blue for five minutes and rinsed in water thrice. Stained sections were treated in series of grades of ethanol $(50 \%, 70 \%, 80 \%, 90 \%$ and $100 \%)$ to differentiate the sections. The differentiated sections were mounted in $25 \%$ glycerol on a clean slide, covered with a cover slip and sealed with nail hardener and properly labeled.

\section{Microscopy}

Microscopic observations were done using a light microscope. Tissues, cells and cell inclusions were identified, described and recorded for taxonomic studies.

\section{Photomicrography}

Photomicrographs of the slides were made using Accu- scope trinocular microscope (ACCU-Scope 3001 LED Trinocular microscope with 3.2 MP CMOS digital camera).

Statistical Analysis

The results of the quantitative anatomical data generated were subjected to single Linkage Cluster Analysis to show if there exists a significant difference in the six taxa studied.

\section{RESULTS AND OBSERVATION}

\section{Anatomical Studies}

The summary of the quantitative anatomical features of the six taxa of Nephrolepis studied (Table 1) was used to generate dendrogram and cluster analysis (Fig. 1). The Dendrogram produces two main clusters comprising Nephrolepis biserrata (Sw.) Schott, and N. exaltata (L.) Schott. while the second cluster is made of N. cordifolia (L.) C. Presl, N. biserrata ver. furcans hort. ex L.H. Bailey and N. undulata (Afzel. ex Sw.) J. Sm. The two main clusters had two sub-clusters each. $N$. biserrata is separated from N. exaltata (i) with unipennate. $N$. exaltata (ii) with bipinnate, which are on the same cluster because they are closely related in having curled and sterile leaflet and some other features e.g. runners. The other sub-cluster gave N. cordifolia and $N$. furcans on the same cluster showing the close relationship (leaflet is compound unipinnate), while N. undulata is separated for being epiphytic.

\section{Artificial taxonomic key to six Nephrolepis taxa generated from the clustered assemblege of Nephrolepis using anatomical characters \\ 1a Fertile leaflet}

2a parallel vein, vein sheath, veinlet ending in sori, trichome glandular

N. biserrata

$2 \mathrm{~b}$ vein not parallel, vein not sheathed, veinlet ending in hydathode, trichome not glandular N. biserrata var. furcans

3a tuber present, mid-rib not thick, trichome present, palisade mesophyll cells cylindrical, root hairs absent N. undulata

$3 \mathrm{~b}$ tuber absent, mid-rib thick, trichome absent, palisade mesophyll cells not cylindrical root hairs present N. cordifolia

1b Leaflet not fertile

4a reticulate vein, stomata largely anomocytic, uniseriate epidermis, leaflet simple, linear

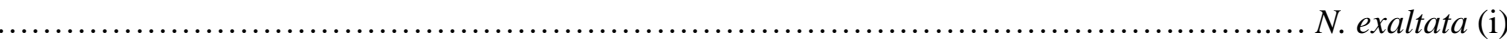

$4 \mathrm{~b}$ non-reticulate vein, stomata not anomocytic epidermis not uniseriate, leaflet coiled N. exaltata (ii) 
This report displays the dendrogram which visually displays a particular cluster configuration of Nephrolepis biserrata, N. cordifolia N. exaltata (i), N. exaltata (ii), N. biserrata var. furcans and N. undulata. Rows that are close together i.e. N. cordifolia and N. biserrata var. furcans, N. exaltata (i) and N. exaltata (ii) have small dissimilarities. Therefore, these taxa are closely related and are very similar. Also, N. undulata is similar to $N$. cordifolia and N. biserrata var. furcans. N. undulata, N. cordifolia and N. biserrata var. furcans are different from N. exaltata (i) and N. exaltata (ii). N. biserrata is very different from other taxa.

Table 1. Summary of the Quantitative Anatomical features of the six Nephrolepis taxa studied.

\begin{tabular}{|c|c|c|c|c|c|c|c|c|c|c|c|c|}
\hline \multirow[b]{2}{*}{ Characters } & \multicolumn{2}{|c|}{ N. biserrata } & \multicolumn{2}{|c|}{ N. cordifolia } & \multicolumn{2}{|c|}{ N. exaltata (i) } & \multicolumn{2}{|c|}{ N. exaltata (ii) } & \multicolumn{2}{|c|}{$\begin{array}{l}\text { N. biserrata } \\
\text { var. furcans }\end{array}$} & \multicolumn{2}{|c|}{ N. undulata } \\
\hline & Abaxial & Adaxial & Abaxial & Adaxial & Abaxial & adaxial & abaxial & Adaxial & Abaxial & adaxial & Abaxial & adaxial \\
\hline$\overline{\text { GCA }}$ & 10.76 & 0 & 8.06 & 0 & 2.58 & 0 & 2.56 & 0 & 10.34 & 0 & 10.22 & 0 \\
\hline GCW & 3.05 & 0 & 1.15 & 0 & 1.64 & 0 & 1.52 & 0 & 2.59 & 0 & 2.52 & 0 \\
\hline GCL & 5.25 & 0 & 2.38 & 0 & 1.21 & 0 & 1.32 & 0 & 3.37 & 0 & 4.75 & 0 \\
\hline SFP & 8 & 0 & 9 & 0 & 4 & 0 & 4 & 0 & 7 & 0 & 4 & 0 \\
\hline STI & 13.45 & 0 & 18.36 & 0 & 29.41 & 0 & 29.34 & 0 & 8.06 & 0 & 13.11 & 0 \\
\hline LEC & 8.96 & 6.2 & 2.89 & 5.8 & 3.15 & 4.5 & 3.12 & 4.3 & 8.47 & 13.84 & 12.46 & 13.3 \\
\hline WEC & 4.06 & 3.92 & 3.15 & 3.65 & 3.55 & 4.08 & 3.45 & 4.04 & 7.24 & 7.2 & 5.85 & 6.68 \\
\hline EPF & 37 & 50 & 34 & 46 & 62 & 82 & 66 & 84 & 31 & 48 & 30 & 39 \\
\hline NTS & 130 & 142 & 0 & 0 & 66 & 80 & 32 & 12 & 15 & 18 & 3 & 5 \\
\hline LTF & 10 & 15 & 0 & 0 & 8 & 8 & 9 & 3 & 10 & 10 & 30 & 30 \\
\hline NVF & 48 & 52 & 35 & 28 & 12 & 18 & 14 & 16 & 40 & 42 & 30 & 35 \\
\hline LVF & 20.5 & 20.5 & 10.7 & 10.7 & 30.3 & 30.5 & 31.2 & 30.4 & 19 & 21 & 20.3 & 20.5 \\
\hline TOV & 0.05 & 0.05 & 0.5 & 0.5 & 0.05 & 0.03 & 0.04 & 0.03 & 0.2 & 0.3 & 0.05 & 0.02 \\
\hline DME & 1.5 & 1.5 & 1.5 & 1.5 & 1.5 & 0.9 & 1.5 & 1.1 & 1.8 & 1.6 & 1.3 & 1.2 \\
\hline TOR & 2.5 & 2.5 & 4 & 4 & 1 & 2 & 1.1 & 1.1 & 0.7 & 0.6 & 0.4 & 0.2 \\
\hline
\end{tabular}

Note: GCA- Guard cell area $\left(\mu \mathrm{m}^{2}\right) \pm$ S.E. N=25; GCW- Guard cell width $(\mu \mathrm{m})$; GCL- Guard cell length $(\mu \mathrm{m})$; SFP- stomata frequency per field; STI- stomata Index \%; LEC- length of epidermal cell $(\mu \mathrm{m})$; WEC- width of epidermal cell $(\mu \mathrm{m})$; EPF- epidermal cell per field $(\mu \mathrm{m})$; NTS- number of trichome per leaflet surface; LTF- length of trichome per field; NVF- number of veins per field; LVF- length of veins per field; TOV- thickness of veins; DME- distance between leaflets margin; TOR- thickness of costa (mid-rib); and veinlet endings.

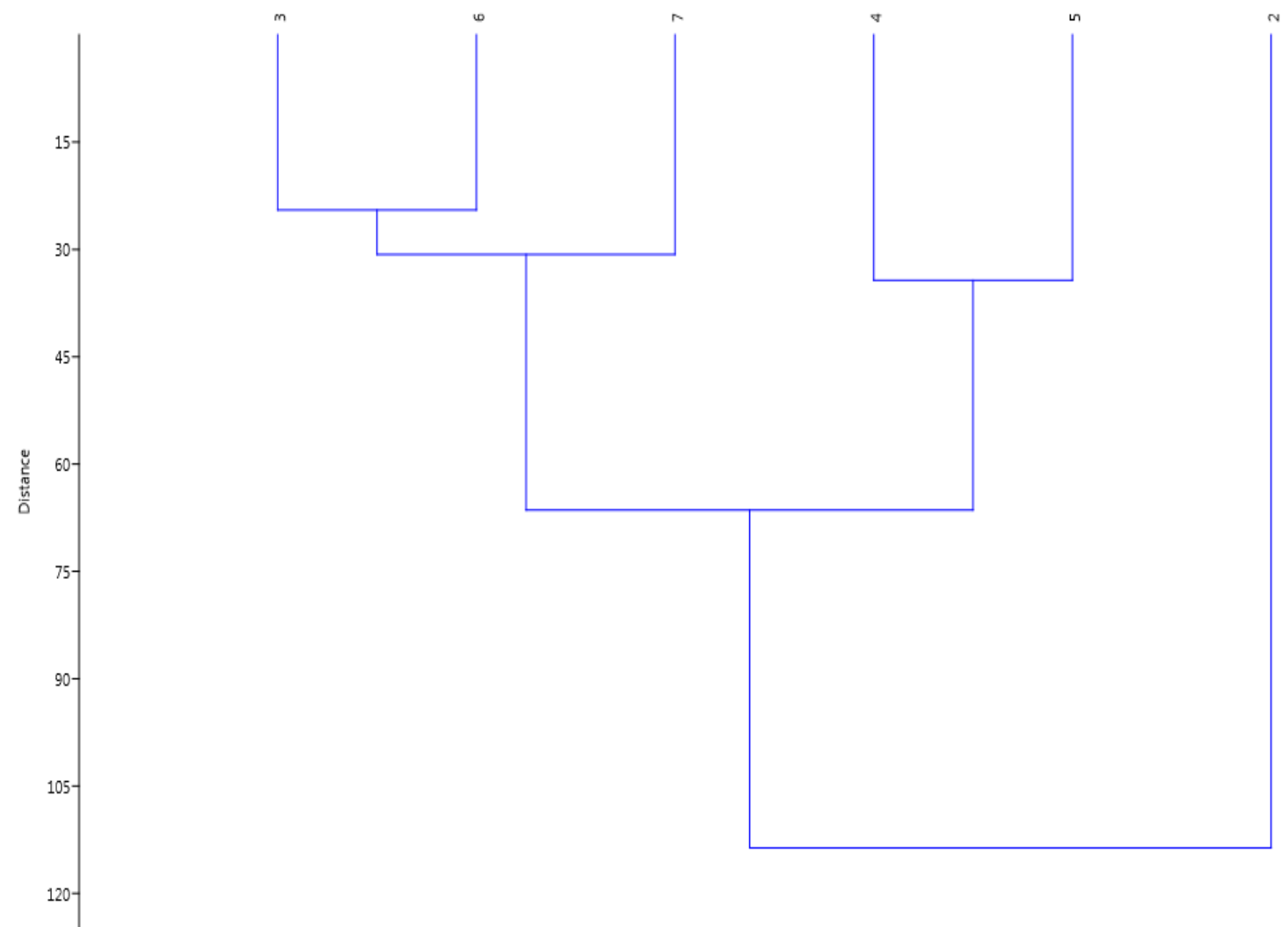

Figure 1. Dendrogram of the six taxa of Nephrolepis studied based on quantitative data from anatomical features. [2Nephrolepis biserrata, 3- N. cordifolia, 4- N. exaltata (i), 5- N. exaltata (ii), 6- N. biserrata var. furcans and 7- N. undulata] 


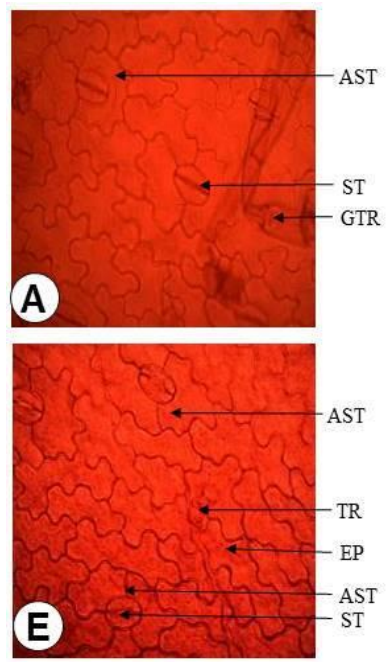

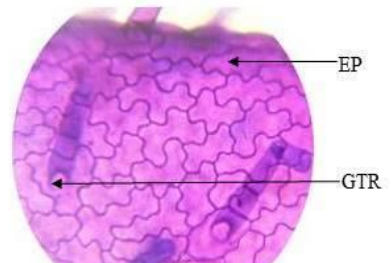

(B)
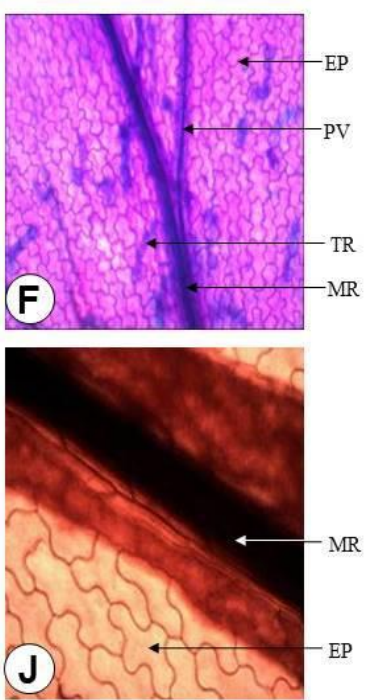

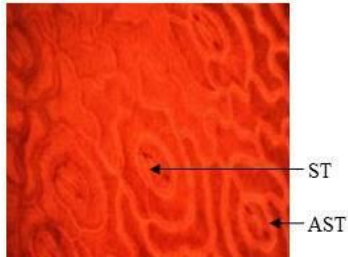

c
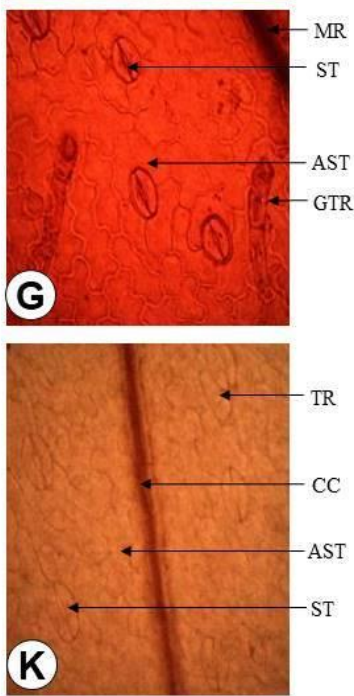
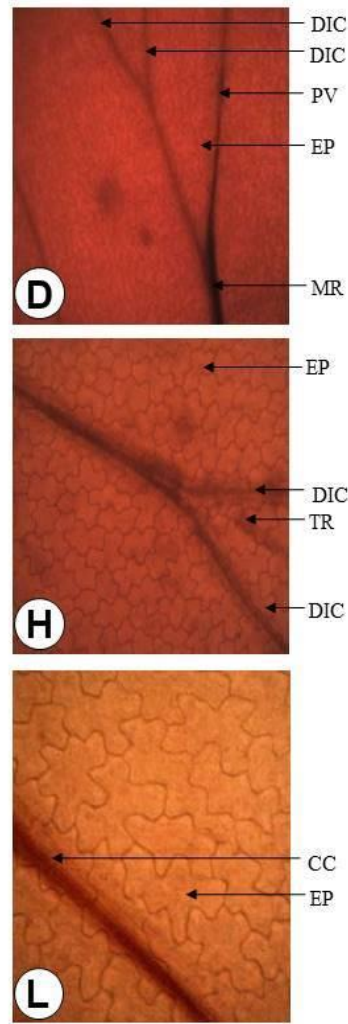

Figure 2. Leaflet anatomical study of Nephrolepis taxa. (AST- anisocytic stomata; EP- epidermal cell; GTR- trichome; STstomata; DIC- dichotomously branched vein; PV- primary vein; MR- mid-rib; VE- vein ending in hydathode/sori; VIdiacytic stomata; DG- deep groove at the margin; CC- costa cell; all in 400x)

\section{Leaflet anatomical study of Nephrolepis biserrata}

(Fig. 2A \& B) Abaxial Surface:

The epidermal cell is irregular and undulating. The anticlinal wall is thin and undulating. Stomata are anisocytic, diacytic and anomocytic. Stomata frequency was 7-9. Long, glandular multicellular trichomes which are numerous are seen on the abaxial surface.

\section{Adaxial Surface:}

Epidermal cells irregular, thin and undulating. No stomata. Long, glandular multicellular trichomes are seen.

\section{Leaflet anatomical study of Nephrolepis cordifolia}

Abaxial Surface:

(Fig. 2C \& D)

The epidermal cell is irregular in shape, thick and undulating. The anticlinal wall is thick and undulating. Some depressions or grooves at the margin. Stomata are anisocytic. Stomata frequency was 8-10. No trichome. Few starch grains are present. There is groove at the margin.

Adaxial Surface:

The epidermal cell is thick, irregular in shape and undulating, no stomata and no trichome. Few starch grains were seen. There is no groove at the margin.

\section{Leaflet anatomical study of Nephrolepis exaltata (i)}

Abaxial Surface:

(Fig. 2E \& F)

The epidermal cell is irregular in shape and anticlinal wall were thin and undulating. Stomata are present and are diacytic, anisocytic and anomocytic. Stomata frequency was 3-5. Trichome was simple, uniseriate, multicellular non-glandular and numerous in the lamina. Few starch grains are present. Depression or groove was seen at the margin.

\section{Adaxial Surface:}

Epidermal cells were irregular in shape, thin and undulating. Stomata are absent. Trichome was simple, uniseriate, multicellular non-glandular and numerous at the lamina. Depression or grooves were seen at the proximal to the median of the margin. 
Abaxial surface:

Epidermal cells were polygonal to irregular in shape. Anticlinal walls were thin and undulating. Anisocytic, diacytic and anomocytic stomata type were seen. Stomata frequency was 2-4. Non-glandular uniseriate multicellular trichomes present. Depression or grooves were seen at the margin.

Adaxial surface:

The epidermal cells were polygonal to irregular in shape. Anticlinal walls seen were thin and undulating. No stomata seen. Non-glandular, uniseriate, multicellular trichomes were seen. Starch grains present and numerous.

Leaflet anatomical study of Nephrolepis biserrata var. furcans

(Fig. 2I \& J) Abaxial surface:

Epidermal cells were irregular, thin and undulating. Diacytic and anisocytic stomata were seen while stomata frequency was 4-9. Few trichomes present. Leaflets form deep depressions or grooves at the tip to form emarginate apex. Numerous starch grains are present.

Adaxial surface:

Epidermal cell was irregular in shape, thin and undulating. Stomata are absent. No trichome. Depression or groove at the leaflet surface.

\section{Leaflet anatomical study of Nephrolepis undulata}

(Fig. 2K \& L)

Abaxial surface:

Epidermal cells were irregular in shape, thin and undulating. Anisocytic stomata were seen. Stomata frequency was 3-5. Few unicellular non-glandular trichomes were seen at the lamina. Few starch grains are seen.

Adaxial surface:

Epidermal cells are irregular in shape. Anticlinal wall was thin and undulating. Stomata are absent. Few unicellular non-glandular trichomes were seen.

\section{DISCUSSION}

The anatomy of the leaflets of Nephrolepis showed various degrees of differences and similarities that can be used for taxonomical studies. These anatomical features such as the absence of trichome in N. cordifolia which can be used to separate this species while the presence of anisocytic stomata shows that they are related and have a common evolutionary origin are a lot of taxonomic values in the six taxa of Nephrolepis studied in this work. The result of this study is similar to other workers who reported similar results. They include Carlquist (1961) who stated that the leaf provides a variety of anatomical features that can be of taxonomic importance. Illoh (1995) reported on Celosia species that the presence and absence of crystals were used in identification, Adedeji (2004) on the anatomy of Emilia species reported the shapes of the mid-ribs are relatively the same in the two species, Ogundipe (2004) on Sapindaceae observed anomocytic stomata in the three species of Blighia studied and Oloyede et al. (2011) on N. biserrata and $N$. undulata reported non-glandular uniserrate multicellular trichome in $N$. biserrata but was absent in $N$. undulata In this study, the leaflets of the six taxa showed remarkable variations on both abaxial and adaxial surfaces. There is variation in the number of veins and length of veins per field as $N$. biserrata recorded the highest of 52 veins on the adaxial surface and 48 veins on the abaxial surface while the lowest of 17 veins on the adaxial and 15 on the abaxial surface in N. exaltata (i) and (ii) The length of veins per field as in $N$. exaltata (i) and (ii) having 30.5 and $30.4 \mu \mathrm{m}$ at the adaxial surface and 30.3 and $31.2 \mu \mathrm{m}$ at the abaxial surface respectively as the highest while $N$. cordifolia recorded the lowest value of $10.7 \mu \mathrm{m}$ at both the adaxial and abaxial surfaces respectively. Epidermal cells in this genus are irregular in shape, with thin undulating anticlinal walls. However anticlinal wall of $N$. biserrata, N. cordifolia and $N$. biserrata var. furcans on both abaxial and adaxial surfaces are thick thus delimiting the taxa. From the study the length of the epidermal cells of members of this genus shows that $N$. biserrata var. furcans has the longest 8.74$18.93 \mu \mathrm{m}$ long and 6.92-8.94 $\mu \mathrm{m}$ wide on the adaxial surface while the least was observed in N. exaltata (i) \& (ii) as $2.28-5.75 \mu \mathrm{m}$ long and $2.65-4.12 \mu \mathrm{m}$ wide. But the abaxial surface of $N$. biserrata var. furcans as the highest with $10.92-16.02 \mu \mathrm{m}$ long and $6.92-7.56 \mu \mathrm{m}$ wide while $N$. exaltata (i) had the lowest with $2.75-3.55$ $\mu \mathrm{m}$ long and 2.85-4.25 $\mu \mathrm{m}$ wide. Based on the epidermal cell lengths Nephrolepis species can be delimited.

Solerender (1908) and Metcalfe \& Chalk (1950) reported that stomata type is of taxonomic value. All the 
six taxa studied are hypostomatic and they are largely anisocytic. In addition, $N$. biserrata, $N$. exaltata (i), $N$. exaltata (ii) and $N$. biserrata var. furcans have diacytic as well as anomocytic. The presence of anisocytic stomata in all the taxa shows that they are related and have a common evolutionary origin and are generic characters for the genus Nephrolepis.

A marked difference in the stomata frequency was reported in the study. For instance, stomata frequency in $N$. cordifolia was $8-10$ which is the highest while $N$. undulata had 3-5 as the least. $N$. biserrata had 6-8, $N$. exaltata (i) \& (ii) 2-4, while $N$. biserrata var. furcans (a variet of biserrata) had 1-3 respectively. These differences in the stomata frequency could be used as taxonomic value to delimit the taxa (Table 1; Fig. 1).

Stomata indices in the members of this genus are different. For example, stomata index in $N$. exaltata (i) was highest with $24.41 \%$ while $N$. biserrata var. furcans had the least with $8.06 \%$. The variation in the stomata index in this study can be reasonably employed in delimiting the Nephrolepis species. Adedeji \& Jewoola (2008) reported that the stomata index is constant for any given species and the value is more uniform on the abaxial surface than the adaxial surface except in an isobilateral leaf.

Essiett et al. (2010) reported that stomatal index and the guard cell area provide values that will serve as parameters for comparison among taxa, which can be useful for identification of the studied taxa. Essiett \& Etukudo (2012) on their study on three species of Acalypha occurring in Nigeria also reported that variation in stomata index and guard cell areas are useful diagnostic tools. This study reported differences in guard cell areas as. $N$. biserrata had the highest guard cell area of 4.70-5.80 $\mu \mathrm{m}$ square long and 2.5-3.6 $\mu \mathrm{m}$ square wide while $N$. exaltata (i) had the least with $1.17-1.25 \mu \mathrm{m}$ square long and $1.52-1.75 \mu \mathrm{m}$ square wide.

The uses of trichomes in delimiting taxa are reported in literature for example Saheed \& Illoh (2010) used the presence and absence of trichomes to separate the genera Senna and Chamaecrista from their initial genus Cassia. N. biserrata recorded the highest number of trichome per leaflet surface with 142 on the adaxial and 130 on the abaxial surface followed with $N$. exaltata (i) having 80 on the adaxial and 66 on the abaxial while $N$. biserrata var. furcans has 18 on the adaxial and 15 on the abaxial and $N$. undulata had the least with 5 on the adaxial and 3 at the abaxial respectively (Table 1). In addition, $N$. biserrata have simple multicellular glandular trichome which is specific to the taxon while N. exaltata (i), N. exaltata (ii) and N. biserrata var. furcans and N. undulata have simple unicellular non-glandular trichome. $N$. cordifolia have no trichome. Trichomes of different types, sizes and numbers are therefore good diagnostic feature for taxonomic studies in this genus (Table 1).

\section{CONCLUSION}

The results from anatomical studies revealed the affinities, similarities and differences among members of the genus Nephrolepis studied. Anatomically, Nephrolepis taxa studied showed generic features common to all the selected taxa. In all the six taxa, vein arrangement was dichotomously branched but the veinlet ending can be grouped into two; the fertile leaflets of $N$. biserrata, $N$. cordifolia and $N$. undulata have their veinlets terminated with sori while the sterile leaflets of $N$. exaltata (i), N. exaltata (ii), and N. biserrata var. furcans do not have sori. Stomata type, stomatal index and stomata area are useful in delimiting the taxa. Anisocytic stomata are common to all. However, the presence of diacytic in N. biserrata, N. exaltata (i), N. exaltata (ii) and $N$. biserrata var. furcans and the presence of anomocytic in $N$. biserrata, $N$. exaltata (i) and $N$. exaltata (ii) clearly demarcate them from the other taxa. The presence of simple multicellular glandular trichomes in $N$. biserrata, simple multicellular non-glandular trichomes in N. exaltata, and simple unicellular non-glandular in $N$. biserrata var. furcans and $N$. undulata is diagnostic while total absence of trichomes in $N$. cordifolia is taxon specific and delimits it from the remaining.

\section{ACKNOWLEDGEMENT}

Authors are thankful to the Botany Department, Obafemi Awolowo University, Ile-Ife, Osun State, Nigeria for providing necessary facilities.

\section{REFERENCES}

Adedeji O (2004) Leaf epidermal studies of the species of Emilia Cass. (Senecioneae, Asteraceae) in Nigeria. Botanical Lithuanica 10(2): 121-133.

Adedeji O \& Jewoola OA (2008) Importance of leaf epidermal characters in the Asteraceae family. Notulae Botanicae Horti Agrobotanici Cluj-Napoca 36(2): 7-16. 
Alston AHG (1959) Ferns and ferns-allies of West Tropical Africa, $2^{\text {nd }}$ edition. Crown Agents for Oversea Governments and Administrations, London, pp. 1-60.

Bhambie S (1965) Studies in Pteridophytes: The Development, Structure and Arrangement of Leaves in some species of Lycopodium. Proceedings of Indian Academy of Science 58: 153-164.

Carlquist S (1961) Comparative plant Anatomy. Holt, Rinehart and Winston, New York Press.

Carrington CM (2003) Families of vascular plants. Botany 307F. University of Toronto. Available from: page.tim.dickinso@utorotoc.ca. (accessed 22 March, 2005).

Cutter GC (1978) Plant Anatomy, Part 1, $2^{\text {nd }}$ edition. Edward Publishers Limited, London, pp. 119-126.

Essiett UA \& Etukudo IS (2012) Leaf epidermal studies of three species of Acalypha Linn. (Euphorbiaceae). Advances in Applied Science Research 3(5): 3185-3199.

Essiett UA (2004) Petiole anatomy for systematic purposes in Eremonastax polysperma, Justica insulari and Asystacia gangetica (Acanthaceae). World Journal of Applied Science and Technology 2(1): 69-75.

Essiett UA, Bala ON \& Agbakahi JA (2010) Pharmacognostic studies of the leaves and stems of Dioda scandens Sw in Nigeria. Archives of Applied Research 2(5) 184-198.

Franco C (1939) Relation between Chromosome Number and the stomata in coffea. Botanical gazette 100: 81782.

Illoh HC \& Inyang UE (1995) Foliar epidermis and petiole anatomy in some Nigerian Solanium Linn. Species in the sub-genus Leptostemonum (BITT) DUN. Climpses in Plant Research 12: 73-86.

Illoh HC (1995) Foliar epidermis and petiole anatomy of four species of Celosia L. in Nigeria. Feddes Repertorium 106(1-2): 15-23.

Kenrick P \& Crane PR (1997) The origin and early evolution of plants on land. Nature 389(4): 33-39.

Metcalfe CR \& Chalk L (1950) Anatomy of the Dicotyledons, $1^{\text {st }}$ edition. Clarendon Press, Oxford, pp. 222234.

Metcalfe CR \& Chalk L (1979) Anatomy of the Dicotyledons, $2^{\text {nd }}$ edition. Clarendon Press, Oxford, pp. 1-75.

Munir M, Khan MA, Ahmed A, Beno A, Ahmed K, Tariq S, Tabassur T, Mukhtar M, Ambreen M \& Bashir S (2011) Foliar Anatomy of some Ethnobotanical Important Species of Wild Edible Fruits of North Pakistan. Journal of Medicinal Plants Research 5(24): 5871-5880.

Naik VN \& Nirgude SM (1981) Anatomy in relation to taxonomy of Chlorophytum (Liliaceae). Indian Journal of Botany 4(2): 48-60.

Ogundipe OT (2004) Foliar micromorphology of the species of Blighia konig (Sapindaceae) in West Africa. Nigerian Journal of Botany 17: 53-61.

Oloyede FA \& Odu EA (2011) Taxonomic Evaluation of Homosporous Leptosporangiate Ferns (Pteridophytes) in South-Western Nigeria. International Journal of Current Research 2(2): 9-17.

Oloyede FA, Akomolafe FG \& Oladipo OT (2011) Comparative Folia Anatomical and Morphological studies of Nephrolepis biserrata (Swartz) Scott and N. undulata (Swartz). SM. in Nigeria. Journal of Science and Technology 31(2): 1-10.

Palmer G \& Tucker AE (1981) A Scanning Electron Microscope Survey of the Epidermis of East Africa, Grasses 1. Smithsonian Contribution to Botany, U.S.A., No. 43.

Saheed SA \& Illoh HC (2010) Important Morphological Characters in Several Species of Cassiinar (Leguminosae) in South-Western Nigeria. Notulae Scientia Biologicae 3(2): 47-56.

Scatena VL, Giuletti AM, Borba EL \& vanderBerge C (2005) Anatomy of the Bracilian Ericolaceae in correlation with taxonomy and habitat using multivariate analysis. Plant Systematics and Evolution 253: 122.

Solerender P (1908) Boodle LA \& Fitsch FE (Transt) Systematic anatomy of Dicotyledons. Clarendon press, Oxford.

Sporne KR (1975) The Morphology of Pteridophytes, $4^{\text {th }}$ edition. Hutchinson and Co. Publishers Limited, London, pp. 1-107.

Watson L \& Dallwitz MJ (1992) The Grass Genera. C.A.B. International. Wallingford, Oxford, 1024 p. 